Int. J. Dev. Biol. 48: 519-527 (2004)

\title{
The countercurrent principle in invasion and metastasis of cancer cells. Recent insights on the roles of chemokines
}

\author{
GHISLAIN OPDENAKKER* and JO VAN DAMME \\ Rega Institute for Medical Research, University Leuven, Leuven, Belgium
}

\begin{abstract}
Chemokine production by cancer cells constitutes a duality. Leukocyte recruitment under the pressure of chemokines may be beneficial for the host or for the tumor. Here, the emphasis will be on the detrimental effects of chemokines in tumor biology. A decade ago, the countercurrent principle of tumor-derived chemokine and peritumoral protease production was formulated to explain chemokine expression as a selective advantage for specific tumors and as a phenotype of invasive and metastasizing cancer cells. Chemoattracted leukocytes may provide trophic factors and produce invasion and metastasis-promoting proteinases. On the basis of the consensus sequence glutamic acid-leucine-arginine (ELR) preceding the canonical cysteine-any amino acidcysteine (CXC), ELR-positive CXC chemokines, such as interleukin-8 and granulocyte chemotactic protein-2, are angiogenic and thus instruct the host to feed the tumor and bring the vessels into closer contact with the tumor cells. These mechanisms may enhance lymphogenic and hematogenic metastasis. Recent research and proofs of this countercurrent concept are here reviewed and compared. In addition, we discuss how alterations in chemokine ligand and receptor expression profiles may contribute to tumor growth, invasion, metastasis and immune evasion. These comparisons imply practical consequences for future cancer diagnosis and therapy. The implications include methods to diminish metastasis by inhibiting angiogenic $\mathrm{CXC}$ chemokine ligands and receptors, therapeutic combinations of chemokine overexpression with antigenic stimuli and cotreatment with angiostatic chemokines and tumor antigens.
\end{abstract}

KEY WORDS: chemokine, gene transfer, chemokine receptor

\section{Introduction}

The understanding of the underlying biochemical events is gradually growing in the case of several classical observations in tumor biology. This statement certainly is applicable for the observations of paraneoplastic effects, tumor-associated macrophages and the countercurrent model of invasion and metastasis. It is well established that many tumors, in comparison with normal cells, overproduce specific proteins by coincidence. At the molecular level, this phenomenon is explained by accumulation of (random) genetic changes that deregulate gene promoter activities and lead to overproduction of specific mRNAs and proteins. If such proteins possess pharmacological activities, the clinical cancer phenotype is extended by paraneoplastic effects. The production of peptide hormones by oat cell tumors of the lungs forms a classical example of this situation. Chemokine expression may also lead to paraneoplastic effects. Dissiminated pustulosis by tumoral expression of interleukin-8 forms an example (Poszepczynska et al., 2001). Expression of macrophage inflam- matory protein- $1 \alpha$ (MIP-1 $\alpha /$ CCL3) by myeloma cells can have bone destruction as a pharmacological effect, which may be mediated by activation of osteoclasts (Choi et al., 2001).

At the microscopic level, the infiltration of leukocytes into tumors is also a classical observation. Although the underlying mechanism may be random and as such the phenomenon may be classified as paraneoplastic, in specific settings, selection of tumor cell clones during cancer progression may occur. Clones with such selective advantage may persist longer in the host. For instance, a tumor cell clone which produces an autocrine growth factor may become independent from serum platelet-derived growth factor. Similarly, clones that produce net proteolytic activity with the capacity to degrade extracellular matrix components may leave efficiently the primary tumor site and invade the surrounding tissues or cross the basement membrane of endothelia and metastasize to distant organs. Invasion and metastasis

Abbreviations used in this paper: CXC, cysteine-any amino acid-cysteine; ELR, glutamic acid-leucine-arginine.

*Address correspondence to: Dr. Ghislain Opdenakker. Rega Institute for Medical Research, University Leuven, Minderbroedersstraat 10, B-3000 Leuven, Belgium. Fax: +32-1633-7340. e-mail: ghislain.opdenakker@rega.kuleuven.ac.be 
of such clones will more readily occur than of clones which overproduce net inhibitory activity against proteases. Cancer cell phenotypes, such as uncontrolled growth and invasive behavior have been extensively reviewed (Coussens and Werb, 2002; Mareel and Leroy, 2003).

Tumor-associated leukocytes were originally conceived as a beneficial host response to tumors. This is certainly the case for immunogenic tumors or when additional immune signaling or insults occur. For instance, a tumor may become necrotic or infected. Furthermore, many cancer treatments, in particular chemotherapy, radiotherapy and immunotherapies induce necrosis and inflammatory signals. In other words, many circumstances exist in which chemokines may be induced in the tumor surroundings and this may account for tumor-associated leukocytes and, indeed, these recruited cells may be detrimental for the tumor and beneficial for the host. A number of experimental conceptual proofs will be given from recent literature (vide infra). In addition, we will review here the current knowledge on another key question. What happens or what is the effect of autonomous chemokine expression by the tumor when no immunological danger signaling occurs? Obviously, leukocytes will be recruited to the tumor and maybe the tumor will strangle itself by the workings of the immune system. In principle, if it were so simple, by such negative selection one would not observe so often tumorassociated leukocytes in diagnostic tumor biopsies. While we were studying chemokine production by cancer cells, we observed that most invasive cancers produced the broadest spectrum and the highest levels of chemokines. For instance, we purified from the human osteosarcoma cell line MG-63 (Fig. 1) the angiogenic and granulocyte chemotactic proteins interleukin-8 (IL-8/CXCL8)(Van Damme et al., 1988), GRO $\alpha / C X C L 1$, granulocyte chemotactic protein-2 (GCP-2/CXCL6) (Proost et al., 1993), the angiostatic CXC chemokine IP-10/CXCL10 (Proost et al., 1993) and monocyte chemotactic protein -1 (MCP-1/CCL2), MCP2/CCL8 and MCP-3/CCL7 (Van Damme et al., 1992).

The early observations that cancer cells produce chemokines, the countercurrent principle of invasion (Opdenakker and Van Damme, 1992), the gene structures and biological functions of chemokines and the consequences for cancer biology were

\section{Chemokines produced by MG-63 cells}

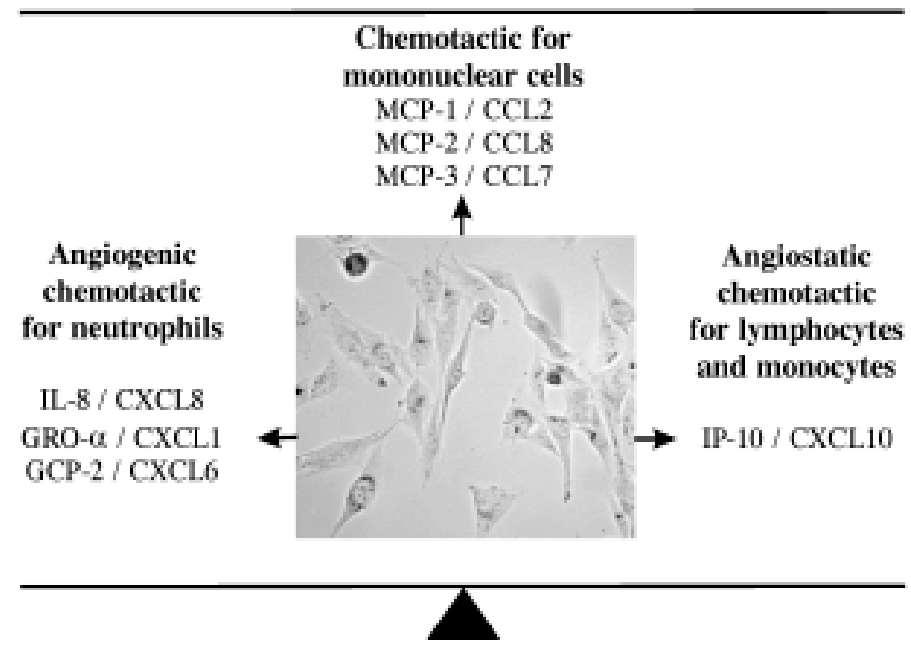

reviewed in 1999 (Opdenakker and Van Damme, 1999) and this theme was discussed in other review articles (Balkwill and Mantovani, 2001; Mareel and Leroy, 2003). Also, the role of proteinases from leukocytes in the invasive process was highlighted in the original countercurrent concept and has meanwhile been documented in vivo(Coussens etal., 2000; Van Coillie etal., $2001)$. The roles played by gelatinase $B /$ matrix metalloproteinase9 in pathology were extensively addressed in a recent extensive review (Van den Steen et al., 2002). We originally coined the name "countercurrent model" for the involvement of chemokines in cancer, because the fluxes of tumor and host cells are opposite: chemoattracted leukocytes and growing vessels (angiogenesis) are towards the tumor, while the invasion of cancer cells is away from the primary tumor site and is facilitated by chemokineinduced proteolysis. By now, almost every type of tumor has been shown to produce chemokines or to be responsive to one or another chemokine. A literature search in the PubMed data library (www.ncbi.nlm.nih.gov) lists about 2000 entries on "chemokines and cancer" and the majority of manuscripts deals with the expression of chemokine ligands or receptors (Tables 1 and 2) in various types of tumors. This observation not only directly explains the so frequent occurrence of tumor-associated leukocytes, but it also suggests that this phenomenon is more than just random coincidence. Therefore, we will focus below on the functional aspects how chemokines may assist tumors and what may be the practical consequences of the countercurrent principle for the oncologist.

\section{How may chemokines help tumors?}

\section{Chemokines may be direct autocrine growth factors for cancer cells}

Particular chemokines have been found to stimulate in an autocrine way the growth of cancer cells. This implies that the tumor cells carry chemokine receptors that transduce a mitogenic signal. In this way IL-8 has been found to be mitogenic for Kaposi sarcoma cells (Masood et al., 2001), ovarian cancer (Xu and Fidler, 2000), colon carcinoma (Brew et al., 2000) and malignant mesothelioma (Galffy et al., 1999). Alternatively, the chemokine Gro$\alpha / C X C L 1$ was originally discovered as a growth factor for melanoma cells (Richmond et al., 1988; Haghnegahdar et al., 2000).

Fig. 1. Invasive tumor cells produce simultaneously various chemokines. Around 1970, invasive primary tumors were systematically cultured to establish new tumor cell lines at the Rega Institute for Medical Research. The corresponding cell lines were named "MG" because "menselijk gezwel" means human tumor. One of these, MG-63 (Billiau et al., 1977) is pictured here and has been widely used for cytokine (fibroblast interferon, interleukin-6) and chemokine production. A number of chemokines that were produced and characterized from MG-63 cells are here classified into the CXC chemokines and the mononuclear cell attractants of the CC family. In terms of angiogenesis a counterbalance exists between the angiogenic and angiostatic CXC chemokines, whereas the effect of CCLs is less documented. This historical example illustrates that tumor cells may produce simultaneously a variety of chemokines and that the biological effects in vivo depend on functional balances between e.g. angiogenesis and angiostasis and of the numbers, types and activation pathways of the chemokine-recruited leukocytes. For chemokine abbreviations see Tables 1 and 2. Photograph and montage by the courtesies of Chris Dillen and Pierre Fiten. 
SDF-1/CXCL12 has been found to stimulate glioblastoma cell proliferation (Barbero et al., 2003). I-309/CCL1 possesses antiapoptotic effects and thus sustains the growth of $T$ cell lymphomas (Van Snick et al., 1996) and adult T cell leukemia cells (Ruckles et al., 2001). Finally, IL-8/CXCL8 has been found to inhibit TNFrelated apoptosis in ovarium carcinoma (Abdollahi et al., 2003).

\section{Chemokines provide paracrine growth advantages via an- giogenesis}

Angiogenesis has been well studied in the biology of organ development, tissue repair and cancer growth and invasion. Vessel growth, relevant for cancer, varies widely (e.g blood and lymph vessels) and is governed by many factors that stimulate (e.g. angiogenesis by vascular endothelial growth factors) or dampen (e.g. angiostatin) proliferation of the various types of endothelial cells (Folkman, 1995). Chemokines belong to these factors and their introduction in the angiogenesis field coincided with the early studies of platelet factor-4/CXCL4, a heparin binding molecule with the CXC signature that possesses strong anti-angiogenetic activity (Maione et al., 1990). Shortly thereafter, IL-8/CXCL8 was discovered as an angiogenic chemokine (Koch et al., 1992; Strieter et al., 1992). The critical difference between the angiogenic and angiostatic CXC chemokines is dependent on a tripeptide ELR motif in front of the CXC (Strieter et al., 1995). According to this rule, the CXC chemokines (without ELR), such as PF-4/CXCL4 (Maione et al., 1990), IP-10/CXCL10 (Arenberg etal., 1996) and Mig/CXCL9 are angiostatic, whereas the ELR ${ }^{+} C X C$ chemokines are angiogenic. Prototypes for the latter subgroup

\section{TABLE 1} CHROMOSOMAL LOCALIZATION AND RECEPTOR USAGE

\begin{tabular}{|c|c|c|c|}
\hline $\begin{array}{l}\text { Systemic } \\
\text { Name }\end{array}$ & Synonym ${ }^{a}$ & Chromosome & Receptor(s) ${ }^{b}$ \\
\hline CCL1 & $\mathrm{I}-309$ & $17 q 11.2$ & CCR8 \\
\hline CCL2 & MCP-1/MCAF & $17 q 11.2$ & CCR2 \\
\hline CCL3 & MIP- $1 \alpha / L D 78 \alpha$ & $17 q 11.2$ & CCR1,CCR5 \\
\hline CCL3L1 & MIP- $1 \alpha / D L 78 \beta$ & $17 q 11.2$ & CCR1, CCR3, CCR5 \\
\hline CCL4 & MIP-1 $\beta$ & $17 q 11.2$ & CCR1, CCR2, CCR5 \\
\hline CCL5 & RANTES & $17 q 11.2$ & CCR1, CCR3, CCR5 \\
\hline CCL7 & MCP-3 & $17 q 11.2$ & CCR1, CCR2, CCR3, CCR5 \\
\hline CCL8 & MCP-2 & $17 q 11.2$ & CCR1, CCR2, CCR3, CCR5 \\
\hline CCL11 & Eotaxin & $17 q 11.2$ & CCR2, CCR3 \\
\hline CCL13 & MCP-4 & $17 q 11.2$ & CCR1, CCR2, CCR3 \\
\hline CCL14 & $\mathrm{HCC}-1$ & $17 q 11.2$ & CCR1, CCR3, CCR5 \\
\hline CCL15 & HCC-2/Lkn-1/MIP-1 $\delta$ & $17 q 11.2$ & CCR1, CCR3 \\
\hline CCL16 & HCC-4/LEC & $17 q 11.2$ & CCR1 \\
\hline CCL17 & TARC & $16 q 13$ & CCR4 \\
\hline CCL18 & DC-CK1/PARC/AMAC-1 & $1 \quad 17 q 11.2$ & Unknown \\
\hline CCL19 & MIP-3ß/ELC/exodus-3 & $9 p 13$ & CCR7 \\
\hline CCL20 & MIP-3 $\alpha /$ LARC/exodus- 1 & $2 q 33-q 37$ & CCR6 \\
\hline CCL21 & 6Ckine/SLC/exodus-2 & $9 p 13$ & CCR7 \\
\hline CCL22 & MDC/STCP-1 & $16 q 13$ & CCR4 \\
\hline CCL23 & MPIF-1/MIP-3 & $17 q 11.2$ & CCR1 \\
\hline CCL24 & MPIF-2/eotaxin-2 & $7 q 11.23$ & CCR3 \\
\hline CCL25 & TECK & $19 p 13.2$ & CCR9 \\
\hline CCL26 & Eotaxin-3 & $7 q 11.23$ & CCR3, CCR10 \\
\hline CCL27 & CTACK/Eskine & $9 p 13$ & CCR10 \\
\hline CCL28 & MEC & & CCR10 \\
\hline
\end{tabular}

a The CCL nomenclature is restricted for human ligands.

${ }^{\mathrm{b}}$ receptor binding by intact or posttranslationally modified chemokine are IL-8/CXCL8 in humans and GCP-2 in the mouse (Strieter et al., 1995b; Belperio et al., 2000). Although it is known that angiostatic chemokines bind to CXCR3 (Proost et al., 2001; Romagnani et al., 2001), it remains not fully understood how these inhibit the angiogenic activity of ELR ${ }^{+} \mathrm{CXC}$ chemokines.

\section{Chemokines enhance invasion}

Invasion defined as the process of cell movement through basement membrane barriers and the dense network of extracellular matrix molecules is in fact a physiological function that leukocytes constantly execute in inflammation. The direction of leukocyte migration is towards increasing chemokine concentrations. Some molecular mechanisms to perform chemotaxis functions rely on the production and function of cytoskeletal motor proteins, secreted proteinases and glycanases and the expression of adhesion molecules, including mucins, selectins, integrins and immunoglobulin family receptors. Chemokines, while attracting leukocytes, often activate the production of such enzymes and cell surface markers. Whereas chemokine actions have been mainly studied in immune responses, these activities have also been observed in specific tumor models. For instance, prostate tumor cells, responding to IL-8/CXCL8 through CXCR2 are more invasive in vitro (Reiland et al., 1999) and chemokines induce migrational responses (chemotaxis and cytoskeletal changes) in various human breast carcinoma cell lines (Youngs et al., 1997). In vivo, the invasive phenotype may be assisted by tumor-derived chemokines. Indeed, expression of IL -8/CXCL8 mRNA in ovarium carcinoma is correlated with histological grading (Davidson et al., 2002). Chemoattracted leukocytes may enhance the local proteinase load and thus assist in the invasive process. Thus, overexpression of mouse granulocyte chemotactic protein-2 (which is one of the most potent neutrophil attractants in the mouse) in human melanoma cells, assisted tumor growth by angiogenesis and induced in vivo gelatinase B/MMP-9 as a matrix enzyme (Van Coillie et al., 2001). In many models, xenografting with chemokineexpressing cancer cells has been used to show chemokine action (i.e. tumor infiltration of leukocytes and proteinase induction) (Melani et al., 1995; see also Tables 3 and 4). It needs to be noticed that in most of these settings a strong immune response is elicited and thus the tumor may eventually grow, but often is rejected by the workings of the hosts immune response (vide infra).

TABLE 2

HUMAN CXC CHEMOKINES: CHROMOSOMAL LOCATION AND RECEPTOR RECOGNITION

\begin{tabular}{clcl} 
Systemic Name & Synonym & Chromosome & Receptor(s) \\
\hline CXCL1 & GRO $\alpha / M G S A-\alpha$ & $4 q 12-q 13$ & CXCR2 \\
CXCL2 & GRO $\beta / M G S A-\beta$ & $4 q 12-q 13$ & CXCR2 \\
CXCL3 & GRO $/$ MGSA- $\gamma$ & $4 q 12-q 13$ & CXCR2 \\
CXCL4 & PF4 & $4 q 12-q 13$ & CXCR3B \\
CXCL5 & ENA-78 & $4 q 12-q 13$ & CXCR2 \\
CXCL6 & GCP-2 & $4 q 12-q 13$ & CXCR1, CXCR2 \\
CXCL7 & NAP-2 & $4 q 12-q 13$ & CXCR2 \\
CXCL8 & IL-8 & $4 q 12-q 13$ & CXCR1, CXCR2 \\
CXCL9 & Mig & $4 q 21.21$ & CXCR3 \\
CXCL10 & IP-10 & $4 q 21.21$ & CXCR3 \\
CXCL11 & I-TAC & $4 q 21.21$ & CXCR3 \\
CXCL12 & SDF-1 $\alpha / \beta$ & $10 q 11.1$ & CXCR4 \\
CXCL13 & BLC/BCA-1 & $4 q 21$ & CXCR5 \\
CXCL14 & BRAK/bolekine & Unknown & Unknown \\
\hline
\end{tabular}




\section{Chemokines enhance metastasis by vessel entry}

After local growth and crossing tissue barriers, the tumor cells may enter blood or lymph vessels. This forms the first phase of tumor cell entry during the process of metastasis. In many ex vivo studies, the expression of chemokines has been associated with higher clinical tumor staging (Table 3). Along this line, studies are available on IL8/CXCL8 in cutaneous melanoma (Nurnberg etal., 1999), malignant melanoma (Singh et al., 1999), colorectal carcinoma (Haraguchi et al., 2002), ovarian carcinoma (Davidson et al., 2002), non-Hodgkin lymphoma (Retzlaff et al., 2002), breast cancinoma (Bendre et al., 2002) and lung cancer (Chen et al., 2003). RANTES/CCL5 was studied in non small cell lung cancer (Moran et al., 2002), whereas MCP-1/CCL2 expression was correlated with glioblastoma (Huang et al., 2002). Whether the process of vessel entry is determined by enzyme induction, by the process of angiogenesis, by both or by still other mechanisms must await further experimentation, e.g. by using specific knockout models or by specifically blocking proteinases or chemokines with monoclonal antibodies.

\section{Chemokines determine the location of secondary tumors}

Once tumor cells have entered the blood or lymph vessels they circulate passively. Studies on the roles played by chemokines in metastasis have been skewed more towards chemokine receptor expression than to chemokine ligand production. One reason for this may be the early finding that CXCR4-positive breast cancer cells are responsive to SDF-1 (Muller et al., 2001). At the time of this discovery, SDF-1 was well known for its homing effect on immature (CD34-positive) progenitor cells in the process of bone marrow repopulation (Aiutti et al., 1997). Meanwhile, VEGF was shown to upregulate CXCR4 in breast carcinoma, possibly in hypoxic zones, making these cells responsive to SDF-1 (Bachelder et al., 2002). SDF-1 also enhances motility and adhesion of lung cancer cells expressing CXCR4 (Kijima et al., 2002) and breast cancer cells (Helbig et al., 2003). Furthermore, the outgrowth of micrometastases in colon carcinoma cells was found to be enhanced by SDF-1 (Zeelenberg et al., 2003).

The expression of chemokine receptors, easily experimentally accessible with the use of fluorescent-activated cell sorting(FACS)-analysis and immunohistopathology, may thus determine the type of tumor that metastasizes, whereas the site of dissemination is dictated by expression of the chemokine ligand. For this process to occur, not only chemokines but also adhesion events need to take place. For instance, it has been found that mouse B16 melanomas, transfected with CXCR4, become more metastatic to the lungs (Murakami et al., 2002) via interaction with endothelial beta1 integrins (Cardones et al., 2003). Another place of SDF-1 expression is the lymph node. This may explain why CXCR4-expressing tumors metastasize to lymph nodes (Kato et al., 2003). SDF-1 expression in the eye has been invoked for cancer spreading to this organ (Chan et al., 2003). Along a similar line, LARC/CCL20 is constitutively expressed in the liver and this ligand interacts with CCR6. The latter receptor is commonly overexpressed in colon, thyroid and ovarian carcinoma. These observations may explain the commonly observed metastases of these tumors to the liver (Dellacassagrande et al., 2003). In the future, it will become clearer whether chemokine ligand and receptor expression determine the metastasis target organ. Such studies can now be done by gene profiling of primary tumors and metastases and by investigating organ specific chemokine ligand and receptor expression profiles (Ohshima et al., 2003).

\section{Chemokine expression may induce immune evasion for specific cancers}

Within the concept that chemo-attracted leukocytes may damage the tumor by increasing the immunogenicity through the action of antigen-presenting cells or by stimulating the adaptive immune response through T-helper or cytotoxic T cells and NK cells, the reduction of chemokine action may enhance immune evasion. This may be caused by diminished chemokine ligand or receptor production or activity. The chemotactic response may be decreased in specific tumor settings. For instance, in patients with primary and metastatic melanoma, circulating monocytes have been found to be less responsive to MCP-1/CCL2 in chemotactic migration than those of controls. Possibly, this is due to deactivation or modulation of the MCP-1-receptor expression on these cells (Muller et al., 1997). In another study on the etiology of cervical carcinoma caused by human papilloma virus oncogenes E6 and $E 7$, it was observed that these oncogenes, individually or acting together, suppressed the production of MCP-1/CCL2 in primary epithelial cells from the female genital tract. Other chemokines, such as IP-10/CXCL10, IL-8/CXCL8 and RANTES/CCL5, were less affected. Furthermore, 4 of 6 cervical carcinoma cell lines that scored positive for human papilloma virus transformation, did not express MCP-1/CCL2. Suppression of MCP-1/CCL2 expression

TABLE 3

\section{CHEMOKINE EXPRESSION EX VIVOIN HUMANS}

\begin{tabular}{|c|c|c|c|}
\hline Chemokine & Tumor & Association & Reference \\
\hline RANTES/CCL5 & Non small cell lung cancer & predictor of survival in stage I NCCLC & Moran et al., 2002 \\
\hline IL-8/CXCL8 & T cell lymphoma & association with disseminated pustulosis & Poszepczynska et al., 2001 \\
\hline IL-8/CXCL8 & Primary cutaneous melanoma & correlation with worse prognosis & Nurnberg et al., 1999 \\
\hline IL-8/CXCL8 & Malignant melanoma & correlation with metastatic phenotype & Singh et al., 1999 \\
\hline IL-8/CXCL8 & Colorectal carcinoma & expression in tumor and serum correlates with liver metastasis, microvessel density & Haraguchi et al., 2002 \\
\hline MCP-1/CCL2 & Glioblastoma & MCP-1 as autocrine growth factor & Huang et al., 2002 \\
\hline IL-8/CXCL8 & Ovarian carcinoma & IL-8 mRNA expression in effusions associated with higher tumor grade & Davidson et al., 2002 \\
\hline IL-8/CXCL8 & $\begin{array}{l}\text { Primary gastrointestinal non Hodgkin } \\
\text { lymphoma }\end{array}$ & higher pretreatment IL-8 serum levels associated with higher stage & Retzlaff et al., 2002 \\
\hline IL-8/CXCL8 & Non small cell lung cancer & higher vessel density, higher metastatic potential in vitro & Chen et al., 2003 \\
\hline IL-8/CXCL8 & Gastric carcinoma & association with vascularity & Kitadai et al., 1998 \\
\hline IL-8/CXCL8 & Malignant melanoma & association with aggressiveness & Kunz et al., 1999 \\
\hline
\end{tabular}


seems to coincide with the program of E6/E7-induced transformation of primary epithelial cells (Kleine-Lowinski et al., 2003).

\section{Therapeutic application of chemokines in cancer}

\section{Factors influencing the effect of intratumoral overexpression of chemokines on antitumoral activity}

Five years ago, it was already clear that the effect of chemokine expression in a tumor was different for immunogenic tumors versus nonimmunogenic tumors. In fact, we questioned whether chemokines are tumor suppressors, since in all the available examples of chemokine gene transfer that demonstrated tumor suppression, secondary immunostimulating signals were provided, e.g. by activation with LPS or by using immunogenic tumors (Opdenakker and Van Damme, 1999; Paul et al., 2002). This statement has only been reinforced by more recent data (Table 4). For instance, whereas IP-10/CXCL10 showed little effect as antitumoral agent by adenoviral expression, in synergy with IL-12, the effects were profound in a murine model of colorectal adenocarcinoma (Narvaiza et al., 2000).

A number of influencing factors need to be stressed here. In many experimental models strong immunogenic signals are provided along with the chemokine signals. In particular, the use of xenografted tumor cells and of viral gene transfer vectors (that confer expression of "non self" viral proteins) provide such signals (Table 4). Immunogenic stimuli are absent in most human tumors. This implies that the positive effects of chemokine gene transfection in experimental animal models (including immunogenic signals) may not necessarily be observed in humans.
In addition, the level of chemokine expression determines the outcome. For example low levels of adenoviral expression of MCP. $1 /$ CCL2 in xenogeneic tumors lead to tumor growth, whereas high expression leads to massive infiltration and tumor rejection (Nesbit et al., 2001). This gene-dose effect seems to be difficult to control in human schemes for gene therapy. Also, the balance of tumoral chemokine production and chemokine production by the surrounding tissue will determine whether a tumor cell (having the corresponding chemokine receptor) will migrate to form secondary tumor sites (Menten et al., 2002).

Therefore, at present one may better advocate to study first the outcome of chemokine gene transfection in syngeneic tumor host models and with nonimmunogenic transfer systems (e.g. by not using viral vector systems). As an alternative, the effect of chemokine function in experimental tumor models can be analysed with the use of inhibitory monoclonal antibodies against chemokine ligands or receptors or by other types of interference with chemokine mRNA or protein. In the situation that the chemokine action is blocked by immune evasion mechanisms (rather than the chemokine expression is enhanced) in the tumor, also secondary immunogenic signals, dose effects and the contributions of the surrounding tissues have to be taken into account. Information in the recent literature is in agreement with this thesis and provides a number of examples of this phenomenon (Table 5). The observation that, in a number of examples, the strategies of chemokine engineering or interference work in vivo, gives hope that biotechnological development is possible. However, the fact that so many different chemokines exist makes the choice more difficult.

\section{TABLE 4}

\section{ANTITUMORAL EFFECTS BY FORCED CHEMOKINE EXPRESSION IN TUMORS IN VIVO}

\begin{tabular}{|c|c|c|c|c|c|}
\hline Chemokine DNA & Vector or antibody & Tumor & Effect on tumor & Immune mediator/response & Reference \\
\hline Human MDC/CCL22 & Adenovirus & murine syngeneic tumors & growth $\downarrow$ & $\mathrm{CD8}^{+}$cytolytic effectMHC I & Lee et al., 2003 \\
\hline Mouse fractalkine & pCDNA3.1/Myc-HisA tag & murine syngeneic Lewis lung & growth $\downarrow$ & $\begin{array}{l}\text { CD8 }{ }^{+} \text {cytolytic effect } \\
\text { CD4 }{ }^{+} \text {helper effect }\end{array}$ & Guo et al., 2003 \\
\hline Mouse MCP-3 & pCMV MCP-3 & $\begin{array}{l}\text { mouse colon rectal cancer cells } \\
\text { (CMT93) in C57BI6 mice }\end{array}$ & $\begin{array}{l}\text { growth } \downarrow \\
\text { metastasis } \downarrow\end{array}$ & increased tumoral leukocytes & Hu et al., 2002 \\
\hline Human MCP-3/CCL7 & parvovirus vector & $\begin{array}{l}\text { human cervical carcinoma in } \\
\text { mouse xenograft }\end{array}$ & growth $\downarrow$ & $\begin{array}{l}\text { activated macrophages } \\
\text { and dendritic cells }\end{array}$ & Wetsel et al., 2001 \\
\hline Human MCP-1/CCL2 & adenovirus & human melanoma xenograft & growth $\downarrow$ (high dose) & $\begin{array}{l}\text { massive monocyte infiltration } \\
\text { at high dosis }\end{array}$ & Nesbit et al., 2001 \\
\hline Human MCP-1/CCL2 & bovine papillomavirus & human malignant glioma xenograft & no effect & $\begin{array}{l}\text { massive numbers of monocytes } \\
\text { and natural killer cells }\end{array}$ & Nagai et al., 2001 \\
\hline $\begin{array}{l}\text { Mouse SLC } \\
\text { Mouse ELC } \\
\text { Mouse SDF-1 } \alpha\end{array}$ & $\begin{array}{l}\text { PCXN2 } \\
\text { pThioHisA }\end{array}$ & $\begin{array}{l}\text { fibrosarcoma or ovarian carcinoma } \\
\text { (immunogenic) }\end{array}$ & growth $\downarrow$ & $\begin{array}{l}\text { T lymphocytes and } \\
\text { adjuvant effect of cytokines }\end{array}$ & Nomura et al., 2001 \\
\hline Human Mig/CXCL9 & adenovirus & human non small cell lung carcinoma & $\begin{array}{l}\text { growth } \downarrow \\
\text { metastasis } \downarrow\end{array}$ & angiogenesis $\downarrow$ & Addison et al., 2000 \\
\hline IP-10 & neutralizing antibody & neuroblastoma syngeneic & growth $\downarrow$ & $\begin{array}{l}\text { CD8 }{ }^{+} \text {induction and } \\
\text { vaccination effect }\end{array}$ & Pertl et al., 2001 \\
\hline LEC/HCC-4/CCL16 & vector transfection & $\begin{array}{l}\text { mouse adenocarcinoma } \\
\text { syngeneic in Balb c mice }\end{array}$ & growth $\downarrow$ & CD8+ and neutrophils & Giovarelli et al., 2000 \\
\hline IP-10 in synergy with IL-12 & $\begin{array}{l}\text { adenovirus vector } \\
\text { no effect of IP-10 alone }\end{array}$ & $\begin{array}{l}\text { syngeneic CT26 mouse colorectal } \\
\text { adenoca rumonia }\end{array}$ & growth $\downarrow$ & $\begin{array}{l}\mathrm{CD}^{+} \text {cells increased } \\
\text { CD8 }{ }^{+} \text {cells increased }\end{array}$ & Narvaiza et al., 2000 \\
\hline Mouse CTACK & adenovirus & syngeneic mouse ovarium carcinoma & growth $\downarrow$ & $\begin{array}{l}\mathrm{CD}^{+}{ }^{+} \text {and } \mathrm{CD} 8^{+} \mathrm{NK} \text { cells } \\
\mathrm{CD} 3^{+} \text {lymphocytes }\end{array}$ & Gao et al., 2003 \\
\hline Mouse SLC & plasmid vector & syngeneic colon carcinoma & growth $\downarrow$ & $\mathrm{CD}^{+}$cells & Vicari et al., 2000 \\
\hline
\end{tabular}




\section{TABLE 5}

\section{INHIBITION OF CHEMOKINES IN VIVO HAS PROTECTIVE EFFECT AGAINST CANCER}

\begin{tabular}{|c|c|c|c|c|}
\hline Inhibition & Tumor & System & Effect & Reference \\
\hline $\begin{array}{l}\text { Antisense human } \\
\text { IL-8 via } \\
\text { adenovirus vector }\end{array}$ & $\begin{array}{l}\text { Transitional cell } \\
\text { carcinoma of bladder }\end{array}$ & $\begin{array}{l}\text { Athymic nude mice } \\
\text { xenograft }\end{array}$ & $\begin{array}{l}\downarrow \text { growth } \\
\downarrow \text { angiogenesis }\end{array}$ & $\begin{array}{l}\text { Inoue et al., } 2001 \\
\text { is }\end{array}$ \\
\hline $\begin{array}{l}\text { Sense and } \\
\text { antisense vectors }\end{array}$ & $\begin{array}{l}\text { Human pancreas } \\
\text { carcinoma }\end{array}$ & $\begin{array}{l}\text { Balb c nude mice } \\
\text { xenograft }\end{array}$ & $\begin{array}{l}\downarrow \text { growth } \\
\downarrow \text { metastasis }\end{array}$ & Shi et al., 1999 \\
\hline Inhibitors of CXCR4 & Human ALL & in vitro & $\begin{array}{l}\downarrow \text { growth } \\
\downarrow \text { migration }\end{array}$ & Juarez et al., 2003 \\
\hline
\end{tabular}

\section{Pharmacological interference on the basis of the countercur- rent model}

Several experimental procedures have been worked out and illustrate that the knowledge of the countercurrent principle can be successfully used for cancer therapy. Most of the chemokine literature on invasion and metastasis promotion is about IL-8/ CXCL8 as an example, and some in vivo successes were obtained by inhibition of chemotaxis or angiogenesis mediated by IL-8/CXCL8. Enprostil is a prostaglandin E2 analogue that blocks IL-8/CXCL8 production (Toshina et al., 2000). Fujisawa and colleagues produced a hexapeptide inhibitor of Gro- $\alpha / C X C L 4$ and IL-8/CXCL8, called antileukinate (Fujisawa et al., 1999 and 2000). Monoclonal antibodies against IL-8/CXCL8 and antileukinate inhibited tumor cell growth and pulmonary metastasis in vivo. Monoclonal antibody against IL-8/CXCL8 was also efficient in inhibiting the progression of malignant pleural mesothelioma in nude mice (Galffy etal., 1999). Rebamipide, an antiulcer agent, reduces the inflammatory potential of Helicobacter pylori by reducing IL-8/CXCL8 production by gastric cancer cells (Masamune et al., 2001). The fusion of a chemokine with a tumor antigen induced potent antitumoral response for IP-10/CXCL10 and MCP-3/CCL7, presumably by recruitment and activation of antigen presenting cells, since $\mathrm{T}$ cell responses were detected (Biragyn et al., 1999). The latter study constitutes another example that chemokine plus a second signal (antigen) will provoke an antitumoral response. Some antitumor agents induce antiangiogenic chemokines (e.g. IP-10/CXCL10) and may be useful for inducing tumor necrosis (Cao et al., 2001). Another mechanism by which chemokine-producing cancer cells may have an advantage is by chemokine-receptor desensitization and reduced chemotaxis (Kurt et al., 2001).

\section{Conclusions}

We here addressed the various possibilities how chemokine expression by cancer cell clones may assist these clones for growth, invasion and metastasis. This knowledge is superimposed on the original findings that tumor-associated leukocytes may dampen tumor growth and invasion. Further conclusions can be drawn by an analysis and comparison of the literature on in vivo overexpression of chemokines in tumor models. First, beneficial effects of tumor-specific chemokine overexpression predominate for the host, if the immune system is activated by a second signal. In other words, a therapeutic effect with reduced tumor growth, invasion and metastasis is observed if, in addition to the chemokine signal, the tumor itself or the used vector signal are immunogenic. The effect may be spectacular with xenografted human tumors in mouse systems. We caution that this is an artificial situation, since most human cancers, even when producing chemokines, do not necessarily provide this additional signal, because they often are poorly immunogenic. The use of immune stimulation may help the host to kill the tumor. Second, angiogenic chemokine expression by tumors needs to be blocked, whereas angiostatic chemokines are best enhanced. Various pharmacological ways to achieve these goals are presently being investigated. Finally, chemokineinduced proteases may be other targets for therapy. Since the countercurrent model is mainly documented with neutrophil chemokines (IL-8/CXCL8 in humans and GCP-2 in mice) and these chemokines induce the release of mainly neutrophil proteases (MMP-8, MMP-9 and neutrophil elastase), these enzymes may in the future become good targets for pharmacological inhibitors in invasive and metastatic cancers.

\section{Acknowledgements}

This study was supported by the Cancer Research Foundation of Fortis AB, the Belgian Federation against Cancer, The Fund for Scientific Research (FWO-Vlaanderen) and the Concerted Research Actions of the Regional Government of Flanders (GOA11 2002-2006). The authors thank Dominique Brabants for secretarial help.

\section{References}

ABDOLLAHI, T., ROBERTSON, N.M., ABDOLLAHI, A. and LITWACK, G. (2003). Identification of interleukin 8 as an inhibitor of tumor necrosis factor-related apoptosis-inducing ligand-induced apoptosis in the ovarian carcinoma cell line OVCAR3. Cancer Res. 63:4521-4526.

ADDISON, C.L., ARENBERG, D.A., MORRIS, S.B., XUE, Y.Y., BURDICK, M.D., MULLIGAN, M.S., IANNETTONI, M.D. and STRIETER, R.M. (2000). The CXC chemokine, monokine induced by interferon-gamma, inhibits non-small cell lung carcinoma tumor growth and metastasis. Hum. Gene Ther. 11:247-261.

AIUTI, A., WEBB, I.J., BLEUL, C., SPRINGER, T. and GUTIERREZ-RAMOS, J.C. (1997). The chemokine SDF-1 is a chemoattractant for human CD34+ hematopoietic progenitor cells and provides a new mechanism to explain the mobilization of CD34+ progenitors to peripheral blood. J. Exp. Med. 185:111-120.

ARENBERG, D.A., KUNKEL, S.L., POLVERINI, P.J., MORRIS, S.B., BURDICK, M.D., GLASS, M.C., TAUB, D.T., IANNETTONI, M.D., WHYTE, R.I. and STRIETER, R.M. (1996). Interferon-gamma-inducible protein 10 (IP-10) is an angiostatic factor that inhibits human non-small cell lung cancer (NSCLC) tumorigenesis and spontaneous metastases. J. Exp. Med. 184:981-992.

BACHELDER, R.E., WENDT, M.A. and MERCURIO, A.M. (2002). Vascular endothelial growth factor promotes breast carcinoma invasion in an autocrine manner by regulating the chemokine receptor CXCR4. Cancer Res. 62:7203-7206.

BALKWILL, F. and MANTOVANI, A. (2001). Inflammation and cancer: back to Virchow? Lancet. 357:539-545.

BARBERO, S., BONAVIA, R., BAJETTO, A., PORCILE, C., PIRANI, P., RAVETTI, J.L., ZONA, G.L., SPAZIANTE, R., FLORIO, T. and SCHETTINI, G. (2003). Stromal cell-derived factor 1 alpha stimulates human glioblastoma cell growth through the activation of both extracellular signal-regulated kinases $1 / 2$ and Akt. Cancer Res. 63:1969-1974.

BELPERIO, J.A., KEANE, M.P., ARENBERG, D.A., ADDISON, C.L., EHLERT, J.E., BURDICK, M.D. and STRIETER, R.M. (2000). CXC chemokines in angiogenesis. J. Leukoc. Biol. 68:1-8.

BENDRE, M.S., GADDY-KURTEN, D., MON-FOOTE, T., AKEL, N.S., SKINNER, R.A., NICHOLAS, R.W. and SUVA, L.J. (2002). Expression of interleukin 8 and not parathyroid hormone-related protein by human breast cancer cells correlates with bone metastasis in vivo. Cancer Res. 62:5571-5579.

BILLIAU, A., EDY, V.G., HEREMANS, H., VAN DAMME, J., DESMYTER, J. GEORGIADES, J.A. and DE SOMER, P. (1977). Human interferon: mass production in a newly established cell line, MG-63. Antimicrob Agents Chemother. 12:11-15. 
BIRAGYN, A., TANI, K., GRIMM, M.C., WEEKS, S. and KWAK, L.W. (1999). Genetic fusion of chemokines to a self tumor antigen induces protective, T-cell dependent antitumor immunity. Nat. Biotechnol. 17:253-258.

BREW, R., ERIKSON, J.S., WEST, D.C., KINSELLA, A.R., SLAVIN, J. and CHRISTMAS, S.E. (2000). Interleukin-8 as an autocrine growth factor for human colon carcinoma cells in vitro. Cytokine. 12:78-85.

CAO, Z., BAGULEY, B.C. and CHING, L.M. (2001). Interferon-inducible protein 10 induction and inhibition of angiogenesis in vivo by the antitumor agent 5,6dimethylxanthenone-4-acetic acid (DMXAA). Cancer Res. 61:1517-1521.

CARDONES, A.R., MURAKAMI, T. and HWANG, S.T. (2003). CXCR4 enhances adhesion of B16 tumor cells to endothelial cells in vitro and in vivo via beta(1) integrin. Cancer Res. 63:6751-6757.

CHAN, C.C., SHEN, D., HACKETT, J.J., BUGGAGE, R.R. and TUAILLON, N. (2003). Expression of chemokine receptors, CXCR4 and CXCR5, and chemokines, BLC and SDF-1, in the eyes of patients with primary intraocular lymphoma. Ophthalmology. 110:421-426.

CHEN, J.J., YAO, P.L., YUAN, A., HONG, T.M., SHUN, C.T., KUO, M.L., LEE, Y.C. and YANG, P.C. (2003). Up-regulation of tumor interleukin-8 expression by infiltrating macrophages: its correlation with tumor angiogenesis and patient survival in non-small cell lung cancer. Clin. Cancer Res. 9:729-737.

CHOI, S.J., OBA, Y., GAZITT, Y., ALSINA, M., CRUZ, J., ANDERSON, J. and ROODMAN, G.D. (2001). Antisense inhibition of macrophage inflammatory protein 1-alpha blocks bone destruction in a model of myeloma bone disease. J. Clin. Invest. 108:1833-1841.

COUSSENS, L.M., TINKLE, C.L., HANAHAN, D. and WERB, Z. (2000). MMP-9 supplied by bone marrow-derived cells contributes to skin carcinogenesis. Cell. 103:481-490.

COUSSENS, L.M. and WERB, Z. (2002). Inflammation and cancer. Nature. 420:860-867. Review.

DAVIDSON, B., REICH, R., KOPOLOVIC, J., BERNER, A., NESLAND, J.M., KRISTENSEN, G.B., TROPE, C.G., BRYNE, M., RISBERG, B., VAN DE PUTTE, G. and GOLDBERG, I. (2002). Interleukin-8 and vascular endothelial growth factor mRNA and protein levels are down-regulated in ovarian carcinoma cells in serous effusions. Clin. Exp. Metastasis. 19:135-144

DELLACASAGRANDE, J., SCHREURS, O.J., HOFGAARD, P.O., OMHOLT, H., STEINSVOLL, S., SCHENCK, K., BOGEN, B. and DEMBIC, Z. (2003). Liver metastasis of cancer facilitated by chemokine receptor CCR6. Scand. J. Immunol. 57:534-544.

FOLKMAN, J. (1995). Angiogenesis in cancer, vascular, rheumatoid and other disease. Nat Med. 1:27-31.

FUJISAWA, N., HAYASHI, S. and MILLER, E.J. (1999). A synthetic peptide inhibitor for alpha-chemokines inhibits the tumour growth and pulmonary metastasis of human melanoma cells in nude mice. Melanoma Res. 9:105-114.

FUJISAWA, N., SAKAO, Y., HAYASHI, S., HADDEN, W.A. 3RD, HARMON, C.L and MILLER, E.J. (2000). alpha-Chemokine growth factors for adenocarcinomas; a synthetic peptide inhibitor for alpha-chemokines inhibits the growth of adenocarcinoma cell lines. J. Cancer Res. Clin. Oncol. 126:19-26.

GALFFY, G., MOHAMMED, K.A., DOWLING, P.A., NASREEN, N., WARD, M.J. and ANTONY, V.B. (1999). Interleukin 8: an autocrine growth factor for malignant mesothelioma. Cancer Res. 59:367-371.

GALFFY, G., MOHAMMED, K.A., NASREEN, N., WARD, M.J. and ANTONY, V.B. (1999). Inhibition of interleukin-8 reduces human malignant pleural mesothelioma propagation in nude mouse model. Oncol. Res. 11:187-194.

GAO, J.Q., TSUDA, Y., KATAYAMA, K., NAKAYAMA, T., HATANAKA, Y., TANI, Y., MIZUGUCHI, H., HAYAKAWA, T., YOSHIE, O., TSUTSUMI, Y., MAYUMI, T. and NAKAGAWA, S. (2003). Antitumor effect by interleukin-11 receptor alphalocus chemokine/CCL27, introduced into tumor cells through a recombinant adenovirus vector. Cancer Res. 63:4420-4425.

GIOVARELLI, M., CAPPELLO, P., FORNI, G., SALCEDO, T., MOORE, P.A., LEFLEUR, D.W., NARDELLI, B., CARLO, E.D., LOLLINI, P.L., RUBEN, S., ULLRICH, S., GAROTTA, G. and MUSIANI, P. (2000). Tumor rejection and immune memory elicited by locally released LEC chemokine are associated with an impressive recruitment of APCs, lymphocytes, and granulocytes. J. Immunol. 164:3200-3206.

GUO, J., ZHANG, M., WANG, B., YUAN, Z., GUO, Z., CHEN, T., YU, Y., QIN, Z. and CAO, X. (2003). Fractalkine transgene induces T-cell-dependent antitumor immunity through chemoattraction and activation of dendritic cells. Int. J. Cancer. 103:212-220.
HAGHNEGAHDAR, H., DU, J., WANG, D., STRIETER, R.M., BURDICK, M.D., NANNEY, L.B., CARDWELL, N., LUAN, J., SHATTUCK-BRANDT, R. and RICHMOND, A. (2000). The tumorigenic and angiogenic effects of MGSA/GRO proteins in melanoma. J. Leukoc. Biol. 67:53-62.

HARAGUCHI, M., KOMUTA, K., AKASHI, A., MATSUZAKI, S., FURUI, J. and KANEMATSU, T. (2002). Elevated IL-8 levels in the drainage vein of resectable Dukes' $\mathrm{C}$ colorectal cancer indicate high risk for developing hepatic metastasis. Oncol. Rep. 9:159-165.

HELBIG, G., CHRISTOPHERSON, K.W. 2ND, BHAT-NAKSHATRI, P., KUMAR, S., KISHIMOTO, H., MILLER, K.D., BROXMEYER, H.E. and NAKSHATRI, H. (2003). NF-kappaB promotes breast cancer cell migration and metastasis by inducing the expression of the chemokine receptor CXCR4. J. Biol. Chem. 278:21631-21638.

HU, J.Y., LI, G.C., WANG, W.M., ZHU, J.G., LI, Y.F., ZHOU, G.H. and SUN, Q.B (2002). Transfection of colorectal cancer cells with chemokine MCP-3 (monocyte chemotactic protein-3) gene retards tumor growth and inhibits tumor metastasis. World J. Gastroenterol. 8:1067-1072.

HUANG, R., LIN, Y., WANG, C.C., GANO, J., LIN, B., SHI, Q., BOYNTON, A. BURKE, J. and HUANG, R.P. (2002). Connexin 43 suppresses human glioblastoma cell growth by down-regulation of monocyte chemotactic protein 1, as discovered using protein array technology. Cancer Res. 62:2806-2812

INOUE, K., WOOD, C.G., SLATON, J.W., KARASHIMA, T., SWEENEY, P. and DINNEY, C.P. (2001). Adenoviral-mediated gene therapy of human bladder cancer with antisense interleukin-8. Oncol. Rep. 8:955-964.

JUAREZ, J., BRADSTOCK, K.F., GOTTLIEB, D.J. and BENDALL, L.J. (2003). Effects of inhibitors of the chemokine receptor CXCR4 on acute lymphoblastic leukemia cells in vitro. Leukemia. 17:1294-1300.

KATO, M., KITAYAMA, J., KAZAMA, S. and NAGAWA H. (2003). Expression pattern of CXC chemokine receptor-4 is correlated with lymph node metastasis in human invasive ductal carcinoma. Breast Cancer Res. 5:R144-150.

KIJIMA, T., MAULIK, G., MA, P.C., TIBALDI, E.V., TURNER, R.E., ROLLINS, B. SATTLER, M., JOHNSON, B.E. and SALGIA, R. (2002). Regulation of cellular proliferation, cytoskeletal function, and signal transduction through CXCR4 and C-Kit in small cell lung cancer cells. Cancer Res. 62:6304-6311.

KITADAI, Y., HARUMA, K., SUMII, K., YAMAMOTO, S., UE, T., YOKOZAKI, H., YASUI, W., OHMOTO, Y., KAJIYAMA, G., FIDLER, I.J. and TAHARA, E. (1998). Expression of interleukin-8 correlates with vascularity in human gastric carcinomas. Am. J. Pathol. 152:93-100.

KLEINE-LOWINSKI, K., RHEINWALD, J.G., FICHOROVA, R.N., ANDERSON, D.J., BASILE, J., MUNGER, K., DALY, C.M., ROSL, F. and ROLLINS, B.J. (2003). Selective suppression of monocyte chemoattractant protein-1 expression by human papillomavirus E6 and E7 oncoproteins in human cervical epithelial and epidermal cells. Int. J. Cancer. 107:407-415.

KOCH, A.E., POLVERINI, P.J., KUNKEL, S.L., HARLOW, L.A., DIPIETRO, L.A., ELNER, V.M., ELNER, S.G. and STRIETER, R.M. (1992). Interleukin-8 as a macrophage-derived mediator of angiogenesis. Science. 258:1798-1801.

KUNZ, M., HARTMANN, A., FLORY, E., TOKSOY, A., KOCZAN, D., THIESEN, H.J., MUKAIDA, N., NEUMANN, M., RAPP, U.R., BROCKER, E.B. and GILLITZER, R. (1999) Anoxia-induced up-regulation of interleukin-8 in human malignant melanoma. A potential mechanism for high tumor aggressiveness. Am. J. Pathol. 155:753-763.

KURT, R.A., BAHER, A., WISNER, K.P., TACKITT, S. and URBA, W.J. (2001). Chemokine receptor desensitization in tumor-bearing mice. Cell. Immunol. 207:81-8.

LEE, J.M., MERRITT, R.E., MAHTABIFARD, A., YAMADA, R., KIKUCHI, T., CRYSTAL, R.G. and KORST, R.J. (2003). Intratumoral expression of macrophage-derived chemokine induces CD4+ T cell-independent antitumor immunity in mice. J. Immunother. 26:117-129.

MAIONE, T.E., GRAY, G.S., PETRO, J., HUNT, A.J., DONNER, A.L., BAUER, S.I, CARSON, H.F. and SHARPE, R.J. (1990). Inhibition of angiogenesis by recombinant human platelet factor-4 and related peptides. Science. 247:77-79.

MAREEL, M. and LEROY, A. (2003). Clinical, cellular, and molecular aspects of cancer invasion. Physiol. Rev. 83:337-376.

MASAMUNE, A., YOSHIDA, M., SAKAI, Y. and SHIMOSEGAWA, T. (2001). Rebamipide inhibits ceramide-induced interleukin-8 production in Kato III human gastric cancer cells. J. Pharmacol. Exp. Ther. 298:485-492. 
MASOOD, R., CAI, J., TULPULE, A., ZHENG, T., HAMILTON, A., SHARMA, S., ESPINA, B.M., SMITH, D.L. and GILL, P.S. (2001). Interleukin 8 is an autocrine growth factor and a surrogate marker for Kaposi's sarcoma. Clin. Cancer Res. 7:2693-2702.

MELANI, C., PUPA, S.M., STOPPACCIARO, A., MENARD, S., COLNAGHI, M.I., PARMIANI, G. and COLOMBO, M.P. (1995). An in vivo model to compare human leukocyte infiltration in carcinoma xenografts producing different chemokines. Int J Cancer. 62:572-578.

MENTEN, P., SACCANI, A., DILLEN, C., WUYTS, A., STRUYF, S., PROOST, P., MANTOVANI, A., WANG, J.M. and VAN DAMME, J. (2002). Role of the autocrine chemokines MIP-1alpha and MIP-1beta in the metastatic behavior of murine T cell lymphoma. J. Leukoc. Biol. 72:780-789.

MORAN, C.J., ARENBERG, D.A., HUANG, C.C., GIORDANO, T.J., THOMAS, D.G., MISEK, D.E., CHEN, G., IANNETTONI, M.D., ORRINGER, M.B., HANASH, S. and BEER, D.G. (2002). RANTES expression is a predictor of survival in stage I lung adenocarcinoma. Clin. Cancer Res. 8:3803-3812.

MULLER, A., HOMEY, B., SOTO, H., GE, N., CATRON, D., BUCHANAN, M.E., MCCLANAHAN, T., MURPHY, E., YUAN, W., WAGNER, S.N., BARRERA, J.L., MOHAR, A., VERASTEGUI, E. and ZLOTNIK, A. (2001). Involvement of chemokine receptors in breast cancer metastasis. Nature. 410:50-56.

MULLER, R., ZHENG, M. and MROWIETZ, U. (1997). Significant reduction of human monocyte chemotactic response to monocyte-chemotactic protein 1 in patients with primary and metastatic malignant melanoma. Exp. Dermatol. 6:8186.

MURAKAMI, T., MAKI, W., CARDONES, A.R., FANG, H., TUN KYI, A., NESTLE, F.O. and HWANG, S.T. (2002). Expression of CXC chemokine receptor-4 enhances the pulmonary metastatic potential of murine B16 melanoma cells. Cancer Res. 62:7328-7334.

NAGAI, M. and MASUZAWA, T. (2001). Vaccination with MCP-1 cDNA transfectant on human malignant glioma in nude mice induces migration of monocytes and NK cells to the tumor. Int. Immunopharmacol. 1:657-664.

NARVAIZA, I., MAZZOLINI, G., BARAJAS, M., DUARTE, M., ZARATIEGUI, M., QIAN, C., MELERO, I. and PRIETO, J. (2000). Intratumoral coinjection of two adenoviruses, one encoding the chemokine IFN-gamma-inducible protein-10 and another encoding IL-12, results in marked antitumoral synergy. J. Immunol. 164:3112-3122.

NESBIT, M., SCHAIDER, H., MILLER, T.H. and HERLYN, M. (2001). Low-level monocyte chemoattractant protein-1 stimulation of monocytes leads to tumor formation in nontumorigenic melanoma cells. J. Immunol. 166:6483-6490.

NOMURA, T., HASEGAWA, H., KOHNO, M., SASAKI, M. and FUJITA, S. (2001). Enhancement of anti-tumor immunity by tumor cells transfected with the secondary lymphoid tissue chemokine EBI-1-ligand chemokine and stromal cell-derived factor-1alpha chemokine genes. Int. J. Cancer. 91:597-606.

NURNBERG, W., TOBIAS, D., OTTO, F., HENZ, B.M. and SCHADENDORF, D. (1999). Expression of interleukin-8 detected by in situ hybridization correlates with worse prognosis in primary cutaneous melanoma. J. Pathol. 189:546-551.

OHSHIMA, K., SUEFUJI, H., KARUBE, K., HAMASAKI, M., HATANO, B., TUTIYA, T., YAMAGUCHI, T., SUZUKI, K., SUZUMIYA, J. and KIKUCHI, M. (2003). Expression of chemokine receptor $\mathrm{CXCR} 3$ and its ligand, mig, in gastric and thyroid marginal zone lymphomas. Possible migration and autocrine mechanism. Leuk. Lymphoma. 44:329-336.

OPDENAKKER, G. and VAN DAMME, J. (1992). Cytokines and proteases in invasive processes: molecular similarities between inflammation and cancer. Cytokine 4:251-258.

OPDENAKKER, G. and VAN DAMME, J. (1992). Chemotactic factors, passive invasion and metastasis of cancer cells. Immunol Today 13:463-464.

OPDENAKKER, G. and VAN DAMME, J. (1999). Novel monocyte chemoattractants in cancer. In: Chemokines and Cancer(Editor. B. Rollins). Humana Press Inc. Totawa, New Jersey, USA, pp. 51-69.

PAU L, S., REGULIER, E., POITEVIN, Y., HORMANN, H. and ACRES, R.B. (2002). The combination of a chemokine, cytokine and TCR-based T cell stimulus for effective gene therapy of cancer. Cancer Immunol. Immunother. 51:645-654.

PERTL, U., LUSTER, A.D., VARKI, N.M., HOMANN, D., GAEDICKE, G., REISFELD, R.A. and LODE, H.N. (2001). IFN-gamma-inducible protein-10 is essential for the generation of a protective tumor-specific CD8 T cell response induced by single-chain IL-12 gene therapy. J. Immunol. 166:6944-6951.
POSZEPCZYNSKA, E., MARTINVALET, D., BOULOC, A., ECHCHAKIR, H., WECHSLER, J., BECHEREL, P.A., BOUMSELL, L., BENSUSSAN, A. and BAGOT, M. (2001). Erythrodermic cutaneous T-cell lymphoma with disseminated pustulosis. Production of high levels of interleukin-8 by tumour cells. $\mathrm{Br}$. J. Dermatol. 144:1073-1079.

PROOST, P., DE WOLF-PEETERS, C., CONINGS, R., OPDENAKKER, G., BILLIAU, A. and VAN DAMME, J. (1993). Identification of a novel granulocyte chemotactic protein (GCP-2) from human tumor cells. In vitro and in vivo comparison with natural forms of GRO, IP-10, and IL-8. J. Immunol. 150:1000-1010.

PROOST, P., SCHUTYSER, E., MENTEN, P., STRUYF, S., WUYTS, A., OPDENAKKER, G., DETHEUX, M., PARMENTIER, M., DURINX, C., LAMBEIR, A.M., NEYTS, J., LIEKENS, S., MAUDGAL, P.C., BILLIAU, A. and VAN DAMME, J. (2001). Amino-terminal truncation of CXCR3 agonists impairs receptor signaling and lymphocyte chemotaxis, while preserving antiangiogenic properties. Blood. 98:3554-3561.

REILAND, J., FURCHT, L.T. and MCCARTHY, J.B. (1999). CXC-chemokines stimulate invasion and chemotaxis in prostate carcinoma cells through the CXCR2 receptor. Prostate. 41:78-88.

RETZLAFF, S., PADRO, T., KOCH, P., OELMANN, E., LUGERING, N., MESTERS R.M. and BERDEL, W.E. (2002). Interleukin 8 and Flt3 ligand as markers of advanced disease in primary gastrointestinal non-Hodgkin's lymphoma. Oncol. Rep. 9:525-527.

RICHMOND, A., BALENTIEN, E., THOMAS, H.G., FLAGGS, G., BARTON, D.E., SPIESS, J., BORDONI, R., FRANCKE, U. and DERYNCK, R. (1988) Molecular characterization and chromosomal mapping of melanoma growth stimulatory activity, a growth factor structurally related to beta-thromboglobulin. $E M B O \mathrm{~J}$. 7:2025-2033.

ROMAGNANI, P., ANNUNZIATO, F., LASAGNI, L., LAZZERI, E., BELTRAME, C., FRANCALANCI, M., UGUCCIONI, M., GALLI, G., COSMI, L., MAURENZIG, L., BAGGIOLINI, M., MAGGI, E., ROMAGNANI, S. and SERIO, M. (2001). Cell cycle-dependent expression of $C X C$ chemokine receptor 3 by endothelial cells mediates angiostatic activity. J. Clin. Invest. 107:53-63.

RUCKES, T., SAUL, D., VAN SNICK, J., HERMINE, O. and GRASSMANN, R. (2001). Autocrine antiapoptotic stimulation of cultured adult T-cell leukemia cells by overexpression of the chemokine I-309. Blood 98:1150-1159.

SHI, Q., ABBRUZZESE, J.L., HUANG, S., FIDLER, I.J., XIONG, Q. and XIE, K. (1999). Constitutive and inducible interleukin 8 expression by hypoxia and acidosis renders human pancreatic cancer cells more tumorigenic and metastatic. Clin. Cancer Res. 5:3711-3721.

SINGH, R.K., VARNEY, M.L., BUCANA, C.D. and JOHANSSON, S.L. (1999) Expression of interleukin-8 in primary and metastatic malignant melanoma of the skin. Melanoma Res. 9:383-387.

STRIETER, R.M., KUNKEL, S.L., ELNER, V.M., MARTONYI, C.L., KOCH, A.E., POLVERINI, P.J. and ELNER, S.G. (1992). Interleukin-8. A corneal factor that induces neovascularization. Am. J. Pathol. 141:1279-1284.

STRIETER, R.M., POLVERINI, P.J., ARENBERG, D.A. and KUNKEL, S.L. (1995a) The role of CXC chemokines as regulators of angiogenesis. Shock. 4:155-160.

STRIETER, R.M., POLVERINI, P.J., ARENBERG, D.A., WALZ, A., OPDENAKKER, G., VAN DAMME, J. and KUNKEL, S.L. (1995b). Role of C-X-C chemokines as regulators of angiogenesis in lung cancer. J. Leukoc. Biol. 57:752-762.

TOSHINA, K., HIRATA, I., MAEMURA, K., SASAKI, S., MURANO, M., NITTA, M. YAMAUCHI, H., NISHIKAWA, T., HAMAMOTO, N. and KATSU, K. (2000). Enprostil, a prostaglandin-E(2) analogue, inhibits interleukin-8 production of human colonic epithelial cell lines. Scand. J. Immunol. 52:570-575.

VAN COILLIE, E., VAN AELST, I., WUYTS, A., VERCAUTEREN, R., DEVOS, R., DE WOLF-PEETERS, C., VAN DAMME, J. and OPDENAKKER G. (2001) Tumor angiogenesis induced by granulocyte chemotactic protein-2 as a countercurrent principle. Am. J. Pathol. 159:1405-1414.

VAN DAMME, J., PROOST, P., LENAERTS, J.-P. and OPDENAKKER, G. (1992) Structural and functional identification of two human, tumor-derived monocyte chemotactic proteins (MCP-2 and MCP-3) belonging to the chemokine family. J. Exp. Med. 176:59-65

VAN DAMME, J., VAN BEEUMEN, J., OPDENAKKER, G. and BILLIAU, A. (1988). A novel, $\mathrm{NH} 2$-terminal sequence-characterized human monokine possessing neutrophil chemotactic, skin-reactive, and granulocytosis-promoting activity. $J$. Exp.Med. 167:1364-1376. 
VAN DEN STEEN, P.E., DUBOIS, B., NELISSEN, I., RUDD, P.M., DWEK, R.A. and OPDENAKKER, G. (2002). Biochemistry and molecular biology of gelatinase $B$ or matrix metalloproteinase-9 (MMP-9). Crit. Rev. Biochem. Mol. Biol. 37:375536.

VAN SNICK, J., HOUSSIAU, F., PROOST, P., VAN DAMME, J. and RENAULD, J.C. (1996). I-309/T cell activation gene-3 chemokine protects murine T cell lymphomas against dexamethasone-induced apoptosis. J. Immunol. 157:25702576.

VICARI, A.P., AIT-YAHIA, S., CHEMIN, K., MUELLER, A., ZLOTNIK, A. and CAUX, C. (2000). Antitumor effects of the mouse chemokine 6Ckine/SLC through angiostatic and immunological mechanisms. J. Immunol. 165:1992-2000.

WETZEL, K., MENTEN, P., OPDENAKKER, G., VAN DAMME, J., GRONE, H.J.,
GIESE, N., VECCHI A., SOZZANI S., CORNELIS J.J., ROMMELAERE J. and DINSART C. (2001). Transduction of human MCP-3 by a parvoviral vector induces leukocyte infiltration and reduces growth of human cervical carcinoma cell xenografts. J. Gene Med. 3:326-337.

XU, L. and FIDLER, I.J. (2000). Interleukin 8: an autocrine growth factor for human ovarian cancer. Oncol. Res. 12:97-106.

YOUNGS, S.J., ALI, S.A., TAUB, D.D. and REES, R.C. (1997). Chemokines induce migrational responses in human breast carcinoma cell lines. Int. J. Cancer.71:257-266.

ZEELENBERG, I.S., RUULS-VAN STALLE, L. and ROOS, E. (2003). The chemokine receptor $\mathrm{CXCR} 4$ is required for outgrowth of colon carcinoma micrometastases. Cancer Res. 63:3833-3839. 